\title{
Medical French and Medical English: General Language Skills for a Bilingual Country/Langage médical francophone et anglophone: habiletés de communication médicales attendues dans un pays bilingue
}

Katherine E. Smith MD, Francois LeBlanc MD, Pierre Cardinal MD, Peter G. Brindley MD

About the Authors
Katherine Smith is a member of the Department of Emergency Medicine at the University of Alberta, in
Edmonton, Alberta. Francois LeBlanc is a member of the Département d'anesthésiologie, Division de Soins
Intensifs, Université Laval, in Québec City, Québec. Pierre Cardinal is a member of the Department of Critical
Care at the University of Ottawa, in Ottawa, Ontario. Peter Brindley (left) is a member of the Division of
Critical Care Medicine at the University of Alberta. Correspondence may be directed to
peter.brindley@albertahealthservices.ca.

Table 1. Sample History Taking/Collecte d'information à I'histoire médicale

\begin{tabular}{|c|c|}
\hline Sample History Taking & $\begin{array}{l}\text { Collecte d'information à l'histoire } \\
\text { médicale }\end{array}$ \\
\hline Do you have pain/chest pain? & $\begin{array}{l}\text { Avez-vous de la douleur/la douleur au } \\
\text { poitrine? }\end{array}$ \\
\hline Where does it hurt? Here? & Ou avez-vous mal? Ici? \\
\hline Do you have neck pain? & Avez-vous mal au cou? \\
\hline Are you short of breath? & Êtes-vous essoufflé? \\
\hline Does it hurt to take a deep breath? & $\begin{array}{l}\text { Avez-vous mal lorsque vous respirer } \\
\text { profondément? }\end{array}$ \\
\hline Are you dizzy? & Êtes-vous étourdi? \\
\hline Did you lose consciousness? & Avez-vous perdu connaissance? \\
\hline Do you have any allergies? & Avez-vous des allergies? \\
\hline Do you take any medications? & Prenez-vous des médicaments? \\
\hline Do you have any health problems? & Avez-vous des problèmes de santé ? \\
\hline Have you had any operations? & $\begin{array}{l}\text { Avez-vous déjà été opéré? ou Avez- } \\
\text { vous déjà subi une opération? }\end{array}$ \\
\hline $\begin{array}{l}\text { When did you last have anything } \\
\text { to eat/drink? }\end{array}$ & $\begin{array}{l}\text { Quand avez-vous mangé/bu pour la } \\
\text { dernière fois? }\end{array}$ \\
\hline When did this happen? & Quand est-ce arrivé? \\
\hline When did your symptoms start? & Quand vos symptômes ont-ils débuté ? \\
\hline How fast were you going? & À quelle vitesse alliez-vous? \\
\hline Were you wearing a seatbelt? & Portiez-vous une ceinture de sécurité? \\
\hline Were airbags deployed? & $\begin{array}{l}\text { Est-ce que les coussins gonflables ont } \\
\text { été déployés? }\end{array}$ \\
\hline Have you been immunized? & Avez-vous déjà été vacciné ? \\
\hline Are you/could you be pregnant? & $\begin{array}{l}\text { Êtes-vous ou pourriez-vous être } \\
\text { enceinte? }\end{array}$ \\
\hline When was your last menstrual period? & $\begin{array}{l}\text { Quand avez-vous eu vos dernières } \\
\text { règles/menstruations? }\end{array}$ \\
\hline
\end{tabular}

\section{In English/en anglais}

It has been argued that Canada contains two solitudes, based primarily upon its European founding languages: English and French. ${ }^{1,2}$ Bringing these solitudes closer requires effort and empathy. It also requires common words and phrases. This is the goal of this modest language primer for acute care practitioners. Many medical practitioners treat language-discordant patients and families (both within Canada and worldwide). Interpreters can be invaluable, and can avoid the loss of confidentiality that occurs if we rely upon family members. However, the unusual hours and time pressures of acute care medicine mean that we cannot assume translators will always be available. Moreover, patients who use translators are often less satisfied with their care, ${ }^{3}$ may be less informed when providing consent, ${ }^{4}$ and may demonstrate less outpatient compliance. ${ }^{5}$ Therefore, it is important that front-line practitioners have basic language skills.

Empathy is integral to patient-focused care. Canadian ${ }^{6}$ and American $^{7}$ data suggest that when we cannot communicate in a patient's native language, we treat that patient differently. Even when we have sufficient time, we are less likely to discuss psychosocial issues or to provide lifestyle counselling. In other words, when we cannot connect by communicating directly, we are probably less connected overall. Some of our humanity may be lost, and patients may find it harder to trust.

Even if we still defer to interpreters, the ability to communicate a few phrases (and the effort demonstrated) can bolster a therapeutic alliance. Full bilingualism usually requires 
immersion and extended practice. ${ }^{8}$ Nevertheless, many of us have basic language skills that can be augmented; therefore, we have provided focused lists (Tables 1-9). Obviously, there are usually many ways to communicate the same point. As such, what follows is neither definitive nor comprehensive. However, medical words and expressions are rarely included in basic language courses and are often hard to find. Regardless, improving communicating in a bilingual country (and in a multilingual world) might just nudge together two other potential solitudes, namely clinicians and patients.

\section{In French/En français}

Pour plusieurs observateurs, le Canada est habité par deux « solitudes », assertion supportée par l'existence de deux langues officielles au pays: l'anglais et le français ${ }^{1,2}$. Bien qu'une attitude basée sur l'empathie et la bonne volonté soit essentielle pour atténuer ces deux « solitudes », l'usage d'un vocabulaire commun est certainement important.

Tant au Canada qu'ailleurs dans le monde, bon nombre de médecins ont l'occasion de prendre soins de patients parlant une langue autre que la leur. Dans de telles circonstances, le support de traducteurs officiels est un incontournable. C'est particulièrement vrai lorsque l'on veut prévenir le bri de confidentialité associé à l'utilisation des membres de la famille comme traducteur. Il n'est malheureusement pas toujours possible de trouver les ressources adéquates de traduction dans un contexte de soins aigue. De plus, on note que les patients ayant eu besoin de traducteurs sont souvent moins satisfaits des soins ${ }^{3}$, moins aptes à formuler un consentement éclairé ${ }^{4}$ et moins enclins à suivre les recommandations médicales en externe ${ }^{5}$. C'est donc dire qu'il est avantageux pour les médecins de soins aigue de posséder des habiletés communicationnelles de base dans de telles circonstances.

L’empathie est partie intégrante de la médecine centrée sur le patient. Fait intéressant, des données médicales tant canadiennes $^{6}$ qu'américaines $^{7}$ semblent démontrer que les médecins abordent différemment les patients parlant une langue autre que la leur. Ils ont moins tendance à discuter des aspects psychosociaux ou à aborder les discussions sur l'hygiène de vie, et ce malgré la disponibilité d'un service d'interprète. Cette barrière de communication semble même déborder le simple obstacle de la langue. Sans une communication directe, le médecin semble moins en phase avec son patient, moins empathique. Un peu d'humanisme dans la pratique peut être perdu dans le processus de traduction et le lien de confiance peut être plus difficile à obtenir.

Il est certain qu'un bilinguisme bilatéral « patient-médecin » est un idéal. Ce n'est toutefois pas toujours la réalité. Malgré
Table 2. Other Useful Phrases/Autres phrases utiles Useful Phrases Phrases utiles

We need to do blood tests. Nous devons faire des tests sanguins.

I am waiting to hear from other specialties. J'attends I'avis des autres spécialistes. He/she needs surgery. Il/elle a besoin d'une opération chirurgicale.

He/she is on life support. Il/elle est maintenu en vie artificiellement.

His/her condition is critical. Il/elle est gravement malade.

Please accept my sincere sympathies. Veuillez recevoir mes condoléances les plus sincères.

Table 3. Medical Conditions and Presentations/Symptomes Medical Conditions and

Presentations Symptomes

Bloody stool

Sang dans les selles

Burn

Contusions/ecchymosis/bruise

Diarrhea

Dysuria

La brûlure

Fracture Les contusions/ecchymoses/bleus

Headache

La diarrhée

Heart attack

Hemorrhage

Hematuria

Infection

La dysurie

Injury

Labor

La fracture

Nausea

Rupture

Seizure

Stroke

Vomiting

Le mal de tête

Une crise cardiaque

L'hémorragie

L' hématurie

L'infection

La blessure

L'accouchement

Nausée ou mal au cœur

La rupture

La convulsion

AVC (un accident vasculaire cérébral) Le vomissement

Table 4. Resuscitation/Réanimation
Resuscitation

Airway

Breathing

Circulation

Bag-mask ventilation

Cardiac arrest

CPR (cardiopulmonary resuscitation)

Chest compressions

Defibrillation

Cardiac pacing

Therapeutic hypothermia

Ventricular tachycardia

Ventricular fibrillation

Pulseless electrical activity

Intubation

\section{Réanimation}

Les voies aériennes/respiratoires

La respiration

Circulation sanguine

Embu

Arrêt cardiaque

RCR (réanimation cardiorespiratoire)

Massage cardiaque

Défibrillation

La stimulation cardiaque

L'hypothermie thérapeutique

Tachycardie ventriculaire

Fibrillation ventriculaire

Dissociation électromécanique Intubation l'utilisation appropriée d'un interprète, la capacité du clinicien à exprimer quelques phrases dans la langue du patient, ou tout au 
Table 5. The Medical Body/Le corps du point de vu médical The Medical Body

\begin{tabular}{ll}
\hline Brain & Le cerveau \\
\hline Skull & Le crâne \\
\hline Head & La tête \\
\hline Spine & La colonne vertébrale \\
\hline Spinal cord & La moelle épinière \\
\hline Lungs & Les poumons \\
\hline Thorax & Le thorax \\
\hline Ribs & Les côtes \\
\hline Breasts & Les seins \\
\hline Heart & Le cœur \\
\hline Ventricles & Les ventricules \\
\hline Atria & Oreillette \\
\hline Liver & Le foie \\
\hline Stomach & L'estomac \\
\hline Intestines & L'intestin \\
\hline Kidneys & Les reins \\
\hline Bladder & La vessie \\
\hline Pelvis & Le bassin \\
\hline Penis & Le pénis \\
\hline Vagina & Le vagin \\
\hline Testicles & Les testicules \\
\hline Ovaries & Les ovaires \\
\hline Uterus & L'utérus \\
\hline Joints & Les articulations \\
\hline Vein & La veine \\
\hline Arteries & Les artères \\
\hline Capillaries & Les capillaires \\
\hline Nerve & Le nerf \\
\hline Lymph node & Le ganglion lymphatique \\
\hline &
\end{tabular}

moins à faire un tel effort, peut faciliter le développement d'une alliance thérapeutique avec le patient et son famille.

Il est clair que pour être à l'aise avec une langue autre que sa langue maternelle, du temps, de la pratique et idéalement une immersion complète sont essentiels ${ }^{8}$. Malgré cet état de fait, nous avons tenté de regrouper des mots et des phrases potentiellement utiles dans des contextes de soins aigus pour faciliter des échanges cliniques minimaux (Tableau 1-9). Nous assumons que l'utilisateur de cet outil possède au moins des connaissances minimales du vocabulaire, de la grammaire et de la prononciation de la langue seconde, suffisantes pour fonctionner dans la vie de tous les jours. Cet outil se veut un petit pas vers un rapprochement de nos «solitudes».

\section{En allant de l'avant/Moving Forward En français/In French}

Le lexique ci-haut est un outil ayant pour but de faciliter, modestement bien sûr, les communications médecins-patients. Ce lexique n'a toutefois pas la prétention de remplacer l'usage d'un interprète médical. En effet, il y a les mots que l'on prononce
Table 6. The Senses/Les sens

\begin{tabular}{ll}
\hline Senses & Les Sens \\
\hline Sight/to see & La vision/voir \\
\hline Smell/to smell & L'odorat/sentir \\
\hline Taste/to taste & Le goût/goûter \\
\hline Hearing/to hear & L'ouïe/entendre \\
\hline Touch/to feel & Le toucher/sentir
\end{tabular}

\section{Table 7. Ordering Laboratory Tests and Medications/ Examens et ordonnances Ordering Laboratory Tests and Medications \\ Examens et ordonnances}

Over-the-counter medications Les médicaments en vente libre

Prescription L'ordonnance

Pill/tablet Pilule/comprimé

Ointment Onguent

Once/twice/three times/tour times daily Une/deux/trois/quatre fois par jour

Blood draw La prise de sang

Red/white blood cells Les globules rouges/blancs

Platelets Les plaquettes

Electrolytes Électrolytes

Creatinine Créatinine

Troponin Troponine

Blood glucose Glycémie

Pregnancy test/BHCG Test de grossesse/BHCG

Urinalysis L'analyse d'urine

Arterial/venous/capillary blood gas Le gaz sanguin artériel/

veineux/capillaire

Swab for culture and sensitivity Prélèvement pour les cultures

Blood culture

L'hémoculture

mais il est aussi important de savoir bien prononcer ces mots et surtout de savoir bien les interpréter. L'objectif de notre réflexion est de sensibiliser les médecins et les responsables de l'enseignement médical à l'impact et aux défis médicaux associés aux barrières linguistiques, dans un pays qui se veut officiellement bilingue.

Le développement du cadre CanMEDS ${ }^{9}$ par le Collège Royal des médecins et Chirurgiens du Canada fut une innovation marquante qui a permis de valoriser, dans les processus d'éducation médicale, des aspects autrement négligés de la pratique médicale. De fait, on s'attend beaucoup plus d'un médecin que le rôle restreint d'un expert des faits ou d'un technicien de pointe. En ce sens, on note qu'un bon nombre d'erreurs médicales évitables sont causées par des problèmes de communication $^{3-5,10-15}$. Exprimé sous un autre angle, les standards attendus en termes d'habiletés de communication ne doivent en rien être moins élevés que nos standards en termes d'habiletés procédurales ou de savoir-faire ${ }^{15}$. Les difficultés engendrées pas ces différences linguistiques patient-médecin ${ }^{3-5}$ peuvent possiblement être atténuées en y mettant un accent 
Table 8. Medical Equipment and Technology/Équipement médical et technologie

\begin{tabular}{ll}
\hline Medical Equipment and Technology & Équipement médical et technologie \\
\hline Monitor & Moniteur \\
\hline Blood pressure cuff & Brassard de tension artérielle \\
\hline Thermometer & Thermomètre \\
\hline Arterial line & Canule artérielle \\
\hline Central line & Voie centrale \\
\hline IV & Cathéter intraveineux ou un soluté \\
\hline Dressing & Pansement \\
\hline Sutures & Points de suture \\
\hline Cast & Plâtre \\
\hline Crutches & Béquilles \\
\hline Wheelchair & Chaise roulante \\
\hline Radiograph & Radiographie \\
\hline CT scan & TDM (tomodensitométrie), le scanner \\
\hline Sonography & Échographie \\
\hline Ventilator & Le ventilateur \\
\hline Dialysis & La dialyse/le rein artificiel \\
\hline
\end{tabular}

approprié et bien balancé dans les objectifs de formation CanMEDS des programmes de résidences.

Dans le même ordre d'idée, il peut être utile de connaître les ressources suivantes : 'International Medical Interpreters Association'16, le 'Minnesota Department of Health' ${ }^{17}$ pour les ressources en anglais et le 'Healthcare Interpretation Network' pour les ressources en français ${ }^{18}$. La plupart des universités canadiennes offrent des cours de langue qui sont disponible pour les membres de la faculté de médecine. On y recommande de se familiariser avec les ressources d'interprétation disponibles dans votre institution. Les dictionnaires en ligne ${ }^{19}$ peuvent être utiles pour le vocabulaire spécifique et la prononciation, mais ne sont pas toujours fiables pour la terminologie médicale. Finalement, et comme les autres aspects dans l'art de pratiquer la médecine... rien ne vaut la pratique régulière de ce que l'on souhaite maîtriser.

\section{In English/en anglais}

The list of questions, words, and phrases presented in Tables 1-9 is modest. Moreover, good communication requires more that just the right words: it involves the way they are said, and how they are interpreted. However, we have offered clinicians a tool to demonstrate their empathy, and to help deliver care that is patient focused. The need for such a primer also highlights the challenges of medical communication in a country that claims official bilingualism.

The CanMEDS framework, ${ }^{9}$ from the Royal College of Physicians and Surgeons of Canada, emphasizes that practitioners are now expected to be more than factual or procedural experts: they are also expected to be communicators.
Table 9. Medical Specialties/ Spécialités médicales

\begin{tabular}{ll}
\hline Medical Specialties & Spécialités médicales \\
\hline Anesthesia & Anesthésie \\
\hline Cardiology/cardiac surgery & Cardiologie/chirurgie cardiaque \\
\hline Dermatology & Dermatologie \\
\hline Emergency medicine & Médecine d'urgence \\
\hline Gastroenterology & Gastroentérologie \\
\hline General surgery & Chirurgie générale \\
\hline Geriatrics & Gériatrie \\
\hline Hematology & Hématologie \\
\hline Intensive care & Soins intensifs \\
\hline Nephrology/urology & Néphrologie/urologie \\
\hline Neurology/neurosurgery & Neurologie/neurochirurgie \\
\hline Obstetrics/gynecology & Obstétrique/gynécologie \\
\hline Oncology & Oncologie \\
\hline Pediatrics & Pédiatrie \\
\hline Pulmonary & Pneumologie \\
\hline Thoracic surgery & Chirurgie thoracique \\
\hline
\end{tabular}

Inadequate communication has also been shown to be a major cause of preventable medical error. ${ }^{3-5,10-15}$ Expressed another way, our "verbal dexterity" should match our procedural dexterity and factual know-how. ${ }^{15}$ CanMEDS does not specifically address the issue of language-discordant patients. However, this is part of a growing realization that communication is one of the strongest tools in a physician's armamentarium. This is presumably true, regardless of whether that communication is with patients, families, or coworkers.

Most Canadian universities run language courses that can be accessed by medical faculty. In addition, organizations such as the International Medical Interpreters Association, ${ }^{16}$ the Minnesota Department of Health, ${ }^{17}$ and the Health Care Interpretation Network ${ }^{18}$ offer resources for practitioners and advice for using interpreters. Online dictionaries ${ }^{19}$ are helpful for vocabulary and pronunciation, but are not always reliable for medical terminology. It is also important to familiarize yourself with local translation services, especially in order to access them in time-sensitive situations. Finally, just as in all aspects of medical mastery, nothing beats regular practice.

\section{References}

1. MacLennan H. Two Solitudes. Toronto (ON): Macmillan Press; 1945.

2. Gagnon L. The 'two solitudes' get more solitary. The Globe and Mail 2012 Feb 4; http://www.theglobeandmail.com/news/politics/the-two-solitudes-getmore-solitary/article545667/. Accessed August 1, 2013.

3. Gany F, Leng J, Shapiro E, et al. Patient satisfaction with different interpreting methods: a randomized controlled trial. J Gen Intern Med 2007;22 Suppl 2:312-8.

4. Clark S, Mangram A, Ernest D, et al. The informed consent: a study of the efficacy of informed consents and the associated role of language barriers. J Surg Educ 2011;68(2):143-7.

5. Gany F, Leng JC, Winston G, et al. Diabetes care and language discordance 
among Chinese and Latino primary care patients. Ethn Dis 2011;21(4):473-9.

6. Rosenberg E, Richard C, Lussier MT, et al. The content of talk about health conditions and medications during appointments involving interpreters. Fam Pract 2011;28:317-22.

7. Eamranond PP, Davis RB, Phillips RS, et al. Patient-physician language concordance and lifestyle counseling among Spanish-speaking patients. J Immigr Minor Health 2009;11(6):494-8.

8. Freed BF, Segalowitz N, Dewey DP. Context of learning and second language fluency in French: comparing regular classroom, study abroad, and intensive domestic immersion programs. Stud Sec Lang Acq 2004;26(2):275-301.

9. Royal College of Physicians and Surgeons of Canada. CanMEDS 2005 framework. Ottawa (ON): The College, 2005;

http://www.royalcollege.ca/portal/page/portal/rc/common/documents/canme ds/framework/the_7_canmeds_roles_e.pdf. Accessed August 1, 2013.

Disponible en français à :

http://www.royalcollege.ca/portal/page/portal/rc/common/documents/canme ds/the_7_canmeds_roles_f.pdf

10. Sutcliffe KM, Lewton E, Rosenthal MM. Communication failures: an insidious contributor to medical mishaps. Acad Med 2004;79(2):186-94.

11. Gawande AA, Zinner MJ, Studdert DM, et al. Analysis of errors reported by surgeons at three teaching hospitals. Surgery 2003;133(6):614-21.

12. Alvarez G, Coiera E. Interdisciplinary communication: an uncharted source of medical error? J Crit Care 2006;21(3):236-42.

13. St. Pierre M, Hofinger G, Buerschaper C, et al. Crisis Management in Acute Care Settings: Human Factors and Team Psychology in a High Stakes Environment. New York: Springer; 2008.
14. Brindley PG, Reynolds SF. Improving verbal communication in critical care medicine. J Crit Care 2011;26(2):155-9.

15. Cyna AM, Andrew MI, Tan SGM, et al. Handbook of Communication in Anaesthesia and Critical Care: A Practical Guide to Exploring the Art. New York: Oxford University Press; 2011.

16. International Medical Interpreters Association. IMIA guide on working with medical interpreters. Salem (MA): The Association;

http://www.imiaweb.org/uploads/pages/380_5.pdf. Accessed August 1, 2013.

17. Minnesota Department of Health. Minnesota refugee health provider guide 2010. Chapter 11 - medical interpreters (revised). St. Paul (MN): The Department, 2010; http://www.health.state.mn.us/divs/idepc/refugee/guide/index.html. Accessed August 1, 2013).

18. Healthcare Interpretation Network. Guide des normes nationales destiné aux services d/interprétation en milieu social -Section 6 - Responsabilités des clients. Toronto (ON): The Network, 2007; http:/healthcareinterpretationnetwork.ca/wordpress/wpcontent/uploads/2012/02/Guide-des-normes-nationales-destiné-aux-service s-dinterprétation-en-milieu-soci.pdf. Accéder le 1 août, 2013. Available in English: http://healthcareinterpretationnetwork.ca/wordpress/wpcontent/uploads/2012/03/National_Standard_Guide_for_Community_Inter preting_Services.v3_new_format_Sep_2011..pdf.

19. Reverso. English to French Medical Dictionary. France: Reverso-Softissimo; http://dictionary.reverso.net/medical-english-french/. Accessed August 1, 2013.

\section{CLASSIFIED \\ (x) COLLINGWOOD GEM HOSPITAL}

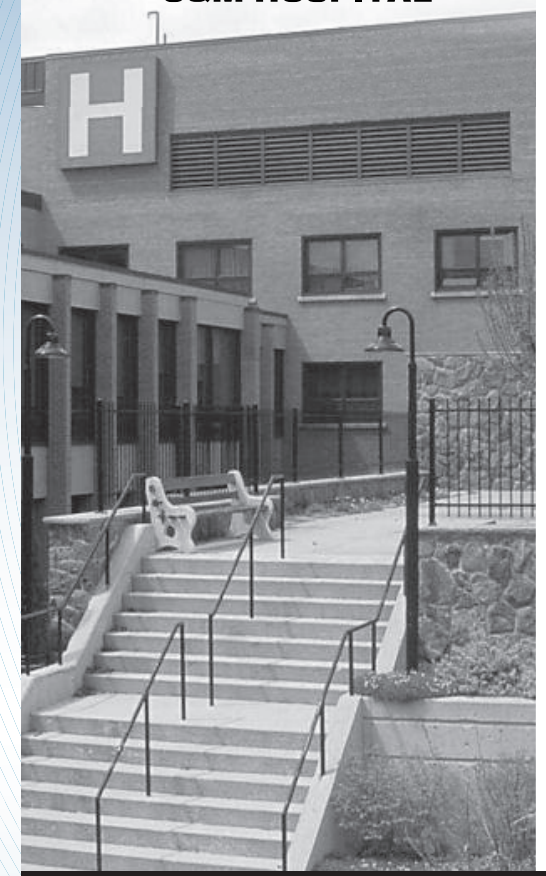

\section{General Internist}

The Collingwood General and Marine Hospital is seeking to add an internist to its current staff. The candidate would be a general internist. An individual with dual specialty certification in Internal medicine, as well as cardiology or respirology would be acceptable, if the candidate was committed to providing general internal medicine care. The role also includes care for patients in the Intensive Care Unit.

\section{The Hospital}

Collingwood Hospital is a 72 bed general hospital serving a local population of 75,000 as well as a substantial seasonal and tourist population. The Emergency Department sees 30,000 visits a year with higher than average acuity. Inpatient services include General Surgery, Orthopaedic Surgery, Anaesthesia, Obstetrics and Gynaecology, and General Medicine including a 5 bed Level II Intensive Care Unit. Outpatient clinics include visiting specialties of nephrology, paediatrics, and ENT. Diagnostic imaging and cardiorespiratory testing continue to expand and are well supported with up to date equipment. There is an outpatient dialysis unit operated as a satellite of a regional program. Oncology services are provided by a regional cancer care center. Noninvasive cardiology care is provided by our cardiologist and our general internist. Interventional cardiology is also provided by the regional tertiary center. The hospital provides orthopaedic surgery services to the local and neighbouring areas. Multiple trauma cases are transferred to a trauma centre.

The catchment area is well served by family physicians and the majority of local residents have primary care services available to them. The hospital is generously supported by the community and is well-equipped. Information technology is well supported and the hospital's electronic medical record is progressing through increased computerization of records. Future plans of the hospital include a new facility to accommodate the needs of the growing population.

\section{Internal Medicine Role Description}

Internal Medicine responsibilities include consultations for inpatients cared for by family physician hospitalists, as well as management of patients in the Intensive Care Unit. The more complex and longer stay critical care patients are transferred to other centres. Consultations are also provided to the Emergency Department. Diagnostic testing includes pulmonary function tests, EKGs, echocardiography, stress tests, Holter monitoring and nuclear cardiology done in conjunction with nuclear medicine specialists. A new recruit would be encouraged to develop a community practice for elective outpatient referrals as well. Internal Medicine on-call would be shared with two other internists. First call for inpatients other than in critical care beds goes to the family physician hospitalists. As all of the hospital's specialist services involve small groups, the family physicians and emergency physicians are accustomed to protecting them from excessive after hours call. 